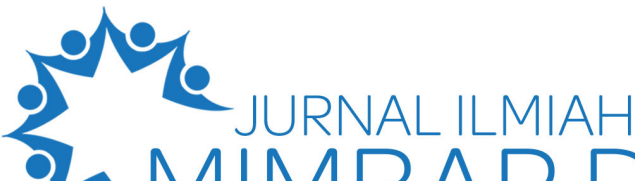 מMIMBAR DEMOKRASI
}

Vol. 21 No. 1 Tahun 2021 | Hal. 48 - 52

\section{Penguatan pendidikan karakter peserta didik melalui peraturan pondok pesantren di era 4.0}

\author{
Febra Anjar Kusuma a, , Nurhayati b, 2*, Susilo c, 3
}

Universitas Lampung, Indonesia

1febraanjar@fkip.unila.ac.id*; ${ }^{2}$ nurhayati.1992@fkip.unila.ac.id*; ${ }^{3}$ susilounila@gmail.com

*Korespondensi Penulis

\begin{tabular}{l}
\hline Informasi artikel \\
\hline Diterima: \\
09-09-2021 \\
Disetujui: \\
02-10-2021 \\
Kata kunci: \\
Pendidikan Karakter \\
Pondok Pesantren \\
Peraturan Pondok
\end{tabular}

\section{Received:}

09-09-2021

Accepted:

02-10-2021

Keywords:

Character Education

Pondok Pesantren

Islamic Traditional School

School Rules

\begin{abstract}
ABSTRAK
Pada era revolusi industri 4.0 sekarang ini penguatan pendidikan karakter dirasa semakin perlu dilakukan, selain untuk menyeimbangkan perubahan yang memengaruhi perilaku individu, juga menjadi salah satu solusi yang dianggap paling tepat dalam menyikapi permasalahan moral dan perilaku menyimpang. Penelitian ini memberikan penjelasan mengenai bagaimana peran dari implementasi peraturan pondok pesantren dalam membentuk dan memperkuat karakter peserta didik/santri di pondok pesantren Darul A'mal. Metode yang digunakan dalam penelitian ini yaitu deskriptif kualitatif. Hasil dalam penelitian ini menunjukkan bahwa implementasi peraturan di pondok pesantren Darul A'mal dapat menjadi solusi untuk memperkuat karakter peserta didik/santri yang ada di dalam pondok. Adapun karakter yang dimaksud yakni karakter religius, disiplin, mandiri, dan tanggung jawab.
\end{abstract}

Copyright (C) 2021 (Febra Anjar Kusuma, Nurhayati \& Susilo). All Rights Reserved

How to Cite: Kusuma, F. A. (2021). Penguatan pendidikan karakter peserta didik melalui peraturan pondok pesantren di era 4.0. Jurnal Ilmiah Mimbar Demokrasi,21(1), 48-52. DOI: http://doi.org/10.21009/jimd.v21i1.23046

\begin{abstract}
Strengthening the character education of students through the regulations of Islamic boarding schools in the 4.0 era. In the current era of the industrial revolution 4.0, strengthening character education is felt to be increasingly necessary, in addition to balancing changes that affect individual behavior, it is also one of the solutions that are considered the most appropriate in addressing moral problems and deviant behavior. This study provides an explanation of how the role of implementing regulations for Islamic boarding schools in shaping and strengthening the character of students/santri in Darul A'mal Islamic boarding schools. The results in this study indicate that the implementation of regulations in the Darul A'mal Islamic boarding school can be a solution to strengthen the character of the students/students in the boarding school. The characters in question are religious, disciplined, independent, polite, and responsible characters.
\end{abstract}

This work is licensed under a Creative Commons Attribution-ShareAlike 4.0 International License. Allows readers to read, download, copy, distribute, print, search, or link to the full texts of its articles and allow readers to use them for any other lanful purpose. The author (s) bolds the copyright.

\section{Pendahuluan}

Era revolusi industri 4.0 yang dikenal dengan kecanggihan digital mempunyai dampak inovasi disrupsi yang secara langsung dapat dirasakan baik dari gaya hidup juga perkembangan teknologi dalam bermasyarakat secara sosial, hal ini ditandai dengan serbuan digitalisasi, seperti adanya kehadiran internet yang telah mengubah pola kehidupan bermasyarakat yang menyebabkan manusia tidak dapat lepas dari internet dan digital (Gazali, 2018; Zulfiati, 2019).
Pesatnya perubahan dan perkembangan peradaban ini, tentunya merubah tatanan dunia di mana bukan hanya sisi baiknya saja namun ada dampak negatif yang menyertai di era ini.

Keadaan negatif yang dimaksud ialah krisis karakter yang dimiliki remaja seperti membolos sekolah meskipun online, tidak ragu untuk menyontek ketika ujian, pornografi, narkoba, tidak adanya prilaku sopan santun kepada yang lebih tua, etika komunikasi yang buruk, game online, pencurian, pelecehan seksual, 


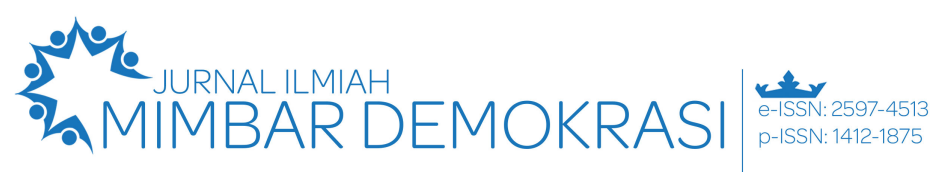

Vol. 21 No. 1 Tahun 2021 | Hal. 48 - 52

pergaulan bebas dan bullying terhdap orang lain yang tidak disukai (Baharun \& Mahmudah, 2018). Untuk menyikapi permasalahan ini salah satu upaya yang dilakukan ialah melalui pendidikan. Peran suatu lembaga pendidikan sangat penting di mana lembaga pendidikan harus mampu mengubah cara belajar, pola berpikir, dan cara bertindak peserta didik untuk mengembangkan kreativitas, inovasi, dan perilaku di berbagai bidang. Pondok pesantren merupakan salah satu lembaga pendidikan formal yang saat ini dilirik dijadikan pilihan paling efektif untuk memperbaiki dan membentuk karakter serta moral peserta didik dengan baik, hal ini biasanya dijadikan pilihan orang tua yang sadar bahwa perkembangan zaman telah membawa pengaruh buruk terhadap generasi muda penerus bangsa.

Sudah banyak penelitian terkait pendidikan karakter di pondok pesantren baik dari segi implementasi dan internalisasi melalui pembiasaan dan habituasi (Supratno et al, 2018), melalui lingkungan, melalui kedisiplinan (Qosidah, Nurhadi, \& Zuhri, 2019) dan juga melalui pembelajaran, namun belum ada penelitian yang lebih terfokus pada aspek yang krusial dan penting dalam menyukseskan pendidikan karakter tersebut, yakni melalui peraturan yang dilakukan oleh peserta didik/santri juga para pengurus/guru/kyai yang ada di pondok. Kenapa peraturan? Hal ini tentunya menjadi sebuah pertanyaan tersendiri yang nantinya akan dijawab dalam penelitian ini. Di samping itu pendidikan karakter dianggap sangat relevan untuk mengatasi dekadensi moral, terkhusus di era revolusi industri 4.0 yang serba digital saat ini agar para santri dapat mewujudkan perilaku yang baik di kehidupan sehari-hari dengan sepenuh hati (Ramdhani \& Waluyo, 2019 ;Risnawati \& Vitasari, 2020). Oleh karena itu penelitian ini berfokus pada penguatan pendidikan karakter peserta didik melalui implementasi peraturan pondok yang berlokasi di pondok pesantren Darul A'mal.

Pondok pesantren Darul A'mal merupakan pondok pesantren salafiyah yang umumnya lebih spesifik dan mempunyai ciri khas (Sumardi, 2012) namun, kenyataannya meskipun salafiyah pondok ini menyelenggarakan sekolah formal berupa madrasah dan SMK di dalamnya, sehingga dapat dikatakan pondok pesantren Darul A'mal merupakan pondok pesantren salafiyah dan juga termasuk ke dalam pondok pesantren moderen, hal ini dikarenakan pondok pesantren Darul A'mal bukan mengajarkan tentang ilmu agama saja namun juga menyesuaikan diri terhadap tuntutan IPTEK. Sejarah pendirian pondok pesantren Darul A'mal pun cukup menjadi sorotan di mana pondok ini didirikan di lingkungan yang dahulunya rawan akan perjudian dan kriminal lainnya. Adapun tujuan pendirian pondok pesantren Darul A'mal yakni meningkatkan keimanan dan ketaqwaan santri, mengembangkan potensi, berilmu, berakhlakul karimah, kreatif, berdedikasi, mandiri, dan bertanggung jawab.

Sebagai sebuah lembaga pendidikan yang berbasis agama fokus pondok pesantren Darul A'mal bukan hanya pada ilmu pengetahuan saja melainkan fokus utama ialah pada peningkatan nilai keagamaan yakni ketaqwaan peserta didik terhadap tuhannya dan moral budi pekerti atau karakter peserta didik. Adapun fungsi dari pendidikan karakter yaitu untuk menanamkan pola berpikir yang baik, berperilaku baik, berhati baik, dengan tidak melupakan potensi dasar peserta didik/santri (Rodliyah, 2016). Banyak upaya tentunya yang dilakukan oleh pondok pesantren Darul A'mal salah satunya yakni melalui sistem peraturan pondok. Melalui peraturan pondok yang diterapkan tentunya dapat menjadi salah satu solusi di bidang pendidikan dalam memperkuat karakter peserta didik/santri di lingkungan pondok pesantren pada era 4.0.

\section{Metode}

Penelitian ini menggunakan jenis penelitian deskriptif dengan pendekatan kualitatif, di mana pengumpulan data menggunakan wawancara, observasi dan dokumentasi. Adapun analisis data menggunakan triangulasi, reduksi, dan penarikan kesimpulan. Dalam penelitian ini peneliti mencoba untuk menggambarkan tentang upaya yang dilakukan pondok pesantren dalam memperkuat karakter peserta didik/santri melalui peraturan pondok serta mengetahui bentukbentuk nilai karakter yang tumbuh dalam diri peserta didik.

\section{Hasil dan pembahasan}

\section{Upaya Penguatan Pendidikan Karakter Melalui Peraturan Pondok Pesantren}

Peraturan pondok pesantren Darul A'mal merupakan salah satu upaya yang dilaksanakan oleh pemimpin pondok untuk menanamkan, mengontrol, membentuk, dan memperkuat karakter peserta didik. Berdasarkan hasil wawancara diketahui bahwa peraturan yang diterapkan sekarang merupakan peraturan yang 
diperbaharui dimana jika dulu peraturan yang ada belum bisa berjalan maksimal masih hal ini ditandai masih adanya peserta didik yang membolos sekolah dan tidur di asrama, menyontek, tidak ikut ibadah dan kegiatan agama tepat waktu, tugas tidak dikerjakan tepat waktu, serta tutur kata yang masih belum halus. Namun seiring perkembangan pesantren maka secara berkala dilakukan evaluasi proses pendidikan yang diberikan didalam pondok khususnya terkait karakter peserta didik. Karena pengadaan evaluasi akan memengaruhi pengembangan sumber daya manusia yang dihasilkan pada perubahan sikap dan perilaku dalam menjalankan peran dan tanggung jawabnya (Mu'is, 2021; Shofiyyah \& Sastraatmadja, 2019). Maka memperbaiki peraturan yang ada di pondok dirasa paling tepat untuk dapat mengontrol, membentuk, dan memperkuat karakter peserta didik/santri.

Peraturan pondok pesantren dibuat dengan sistem yang matang, terlihat pada setiap kegiatan keagamaan dan kegiatan sehari-hari yang dilakukan oleh peserta didik/santri memiliki panduan dan acuan yang jelas akan hukuman yang diterima jika tidak melaksanakan kegiatan sesuai dengan aturan yang ada. Adapun hukuman yang diberikan oleh pondok disesuaikan dengan tingkat pelanggaran dan kegiatannya. Lebih dari itu tingkat pengawasan peraturan pun diperhitungkan, di mana ada bagian-bagian untuk mengakomodasi setiap pelaksanaan kegiatan seperti, adanya seksi agama di mana mereka bertugas untuk mengawasi para peserta didik/santri untuk menjalankan ibadah berjamaah, kegiatan mengaji, shalat malam, dan kegiatan agama lainya. Seksi kebersihan di mana bertugas untuk mengawasi kegiatan piket para santri seperti piket membersihkan halaman pondok, masjid, kamar, dan lingkungan pondok. Seksi keputrian dan keputraan bertugas untuk mengawasi pakaian yang dikenakan harus sesuai dengan aturan pondok, rambut di setiap santri putra, tata karma dan perilaku (sopan santun) baik dalam perilaku dan ucapan kepada teman sebaya dan orang yang lebih tua.

Terakhir yakni seksi keamanan di mana tugasnya adalah mengawasi santri yang melakukan pelanggaran seperti membawa HP tanpa izin, keluar masuk pondok tanpa izin, tidak melaksanakan hukuman dari pelanggaran seksi lain, dan terlambat ataupun membolos sekolah. Adapun hukuman yang akan diterima dari berbagai seksi yaitu 1) Seksi agama, jika tidak melaksanakan kegiatan sholat berjamaah, mengaji, dan kegiatan agama lainya maka hukuman yang akan diterima yaitu mendapatkan I'lan (denda) berupa uang, disebutkan namanya di pengumuman dengan speaker, dan harus menghafalkan surat/dalil tertentu. 2) Seksi kebersihan jika melanggar seksi ini maka santri akan diberikan hukuman I'lan, namanya disebutkan di speaker pengumuman, dan diberikan tugas 2 kali lipat dari jadwal piket yang sudah diberikan. 3) Seksi keputrian dan keputraan, jika melanggar seksi ini maka santri akan mendapatkan hukuman I'lan, namanya disebutkan di speaker pengumuman. 4) Seksi keamanan, jika melanggar seksi ini maka akan mendapatkan hukuman berupa I'lan, namanya disebutkan di speaker pengumuman, dilaporkan langsung ke ustad dan ustadzah, menghafal alquran, dll. Lebih lanjut jika pelanggaran ini sering dilakukan maka akan ada evaluasi di mana setiap pelanggaran akan mendapatkan penambahan hukuman sesuai dengan apa yang dilanggar.

Adanya hukuman dalam peraturan pondok dianggap sebagai bagian dari upaya tindakan tegas yang diberikan kepada peserta didik/santri karena telah melanggar ketentuan ataupun peraturan yang sudah ditentukan. Tujuan dari hukuman sendiri ialah untuk memperbaiki diri sendiri baik dari segi jasmani dan rohani sehingga dapat menghindari hukuman berikutnya dari peluang pelanggaran yang akan datang. Hal ini didukung dengan pernyataan Maarif (2018) bahwasanya menumbuhkan karakter peserta didik/santri dapat melalui hukuman sebagai salah satu strategi dalam pendidikan karakter.

Upaya penguatan pendidikan karakter melalui peraturan pondok menjadi salah satu model pembelajaran pendidikan karakter yang dapat diterapkan diberbagai sekolah dan pondok pesantren. Hal ini dikarenakan peran peraturan/tata tertib yang ada di suatu lingkungan pendidikan baik formal dan non-formal pastinya akan mempengaruhi pencapaian tujuan pembelajaran dan pendidikan yang sesuai dengan visi, misi dan tujuan sekolah ataupun pondok pesantren tersebut. Peraturan yang direncanakan dengan matang dijalankan secara sistematis dan diawasi dengan simultan maka akan mewujudkan karakter yang kuat dan tata krama yang baik yang diwujudkan melalui tata kelakuan yang baik sesuai dengan norma sosial. Artinya peraturan/tata tertib dan tata krama sangat penting untuk penanaman nilai-nilai spiritual dalam membentuk karakter para peserta didik/santri (Nopianti, 2018). Adapun upaya serupa juga dilakukan di pondok Roudhotutolibin di mana pembentukan karakter pada peserta didik dilakukan dengan 


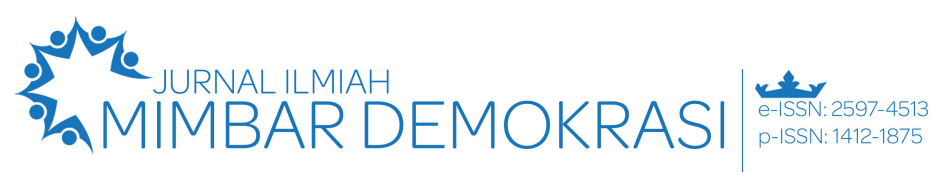

Vol. 21 No. 1 Tahun 2021 | Hal. 48 - 52

adanya upaya dan rencana yang telah dibukukan dalam buku peraturan disiplin santri yang di antaranya menyiapkan tugas piket, etika izin, serta berbagai jenis peraturan dengan konsekuensi hukuman apabila melanggar (Hasan, 2016).

Peraturan yang dilaksanakan di pondok pesantren Darul A'mal ini tentunya berorientasi pada subkultur komponen inti yang berpusat pada kepemimpinan kiai yang mandiri dan tidak terkooptasi oleh pemerintah yang mempunyai value budaya pesantren yang artinya pesantren mempunyai hak penuh terhadap aturan yang dilaksanakan di dalamnya (Zuhriy, 2011) salah satunya menerapkan metode pendidikan karakter melalui metode pembiasaan, nasehat, dan hukuman (Jannah, 2019) yang ada di dalam sebuah peraturan pondok. Proses penanaman nilai karakter pada peserta didik/santri melalui serangkaian kegiatan tentunya disertai dengan pengawasan dan pendampingan sehingga sebagai seorang individu mampu memahami, mengalami, dan mengintegrasikan nilai karakter tersebut menjadi core value sehingga peserta didik/santri dapat mengambil keputusan dengan bijak, mempraktikkannya juga berkontribusi dalam kehidupan sosial masyarakat (Risnawati \& Vitasari, 2020).

\section{Nilai-Nilai Karakter Peserta Didik/Santri Pondok Pesantren Darul A'mal}

Adapun nilai-nilai karakter yang ditanamkan di dalam pondok pesantren Darul A'mal yakni karakter religius, toleransi, mandiri, jujur, bertanggungjawab dan disiplin. Melalui habituasi pondok pesantren di mana di dalamnya terbiasa untuk menjalankan dan mematuhi peraturan dalam kegiatan sehari-hari peserta didik/santri secara otomatis maka karakterkarakter tersebut dapat terbentuk dalam diri peserta didik/santri.

Tabel 1. Hasil Penguatan Pendidikan Karakter di Pondok Pesantren Darul A'mal
\begin{tabular}{|c|c|l|}
\hline NO & KARAKTER & \multicolumn{1}{|c|}{ KEGIATAN } \\
\hline 1 & Religius & $\begin{array}{l}\text { Melaksanakan kegiatan ibadah dan keagamaan seperti } \\
\text { megaji kitab, dan mengucapkan salam }\end{array}$ \\
\hline 2 & Disiplin & $\begin{array}{l}\text { Memakai pakaian seragam, tepat waktu masuk ke kelas, } \\
\text { tepat waktu dalam mengumpulkan tugas, menaati peraturan } \\
\text { sekolah dan pondok pesantren, }\end{array}$ \\
\hline 3 & Mandiri & $\begin{array}{l}\text { Tidak ada ketergantungan kepada orang lain dan orang tua, } \\
\text { mencuci, menyetrika, belajar, menjaga kesehatan, menjaga } \\
\text { kebersihan, yang dilakukan sendiri }\end{array}$ \\
\hline 4 & Tangungjawab & $\begin{array}{l}\text { Melaksanakan tugas yang diberikan dengan baik seperti } \\
\text { melaksakan tugas piket membersihkan mushola, kamar, dlsb } \\
\text { dan mau menerima dan melaksanakan hukuman jika telah } \\
\text { lalai dengan tugas yang diberikan. }\end{array}$ \\
\hline
\end{tabular}

Namun jika difokuskan pada peran dari implementasi peraturan pondok pesantren maka ada beberapa karakter yang kuat terbentuk yaitu karakter religius, disiplin, mandiri, dan tanggung jawab, untuk lebih jelasnya dapat dilihat pada tabel 1.

Nilai karakter religius, disiplin, mandiri, dan tanggung jawab yang tercermin dalam diri peserta didik/santri merupakan bentuk dari ketegasan dan maksimalnya sistem tata peraturan yang dilaksanakan oleh semua penghuni pondok pesantren, yakni baik dari pemimpin atau kiyai, pembina, guru, ustad, dan ustadzah juga para santriwati dan santriwan dalam pembiasaan kehidupan sehari-hari di pondok.

Keberhasilan pendidikan karakter ini tentunya karena paksaan dari peraturan yang ada dan adanya rutinitas kegiatan yang dijalani dalam kehidupan sehari-hari yang secara otomatis melekat kuat kepada peserta didik/santri meskipun penanaman pendidikan karakter ini tidak dilakukan secara langsung dan tidak formal (Sumardi, 2012). Karakter baik diwujudkan dalam sikap dan perilaku dalam kehidupan sehari-hari sehingga, seseorang dapat dikatakan berkarakter baik apabila mereka dapat melakukan hal-hal baik terhadap Tuhan Yang Maha Esa, lingkungan, diri sendiri, sesama manusia, bangsa, dan negara (Dahlan 2016). Pondok pesantren Darul A'mal optimis dan konsisten terhadap peraturan yang telah dilakukan untuk menjaga pribadi peserta didik/santri dari derasnya budaya barat, perkembangan IPTEK, dan perkembangan global yang masuk ke Indonesia (Wiranata, 2019).

Berdasarkan kegiatan dan hasil penelitian maka dapat dijelaskan karakter disiplin ialah berperilaku, bertabiat, berkepribadian, bersifat, dan berwatak dalam keadaan tertib pada suatu keadaan yang sudah ditentukan secara tertib, teratur, dan seharusnya sehingga tidak terjadi pelanggaran-pelanggaran baik langsung maupun tidak langsung (Alfath, 2020). Karakter religius merupakan perilaku tatat kepada Allah swt, melakukan ibadah dengan baik, dan juga tidak melakukan hal-hal yang dilarang oleh agama. Karakter mandiri ialah di mana seseorang individu dapat melakukan segalanya sendiri tanpa campur tangan, menyusahkan, ataupun pertolongan orang lain. Terakhir karakter tanggung jawab ialah perilaku seseorang yang melaksanakan tugas ataupun kegiatan, dan pekerjaan dengan baik sesuai dengan ketentuan.

\section{Kesimpulan}

Upaya penguatan pendidikan karakter melalui peraturan yang ada di pondok pesantren Darul A'mal di Era 4.0 terbukti berhasil. Di mana peraturan pondok dilaksanakan secara terprogram dan sistematis dari santri oleh santri. 
Pengawasan yang terstruktur dari santri dan dikontrol oleh pengurus menjadi salah satu solusi keberhasilan implementasi peraturan yang ada dalam memperkuat karakter peserta didik. Adapun nilai-nilai karakter yang terbentuk dan kuat di pondok pesantren Darul A'mal yaitu karakter religius, disiplin, mandiri, sopan santun, dan bertanggung jawab.

\section{Referensi}

Alfath, K. (2020). Pendidikan karakter disiplin santri di Pondok Pesantren Al-Fatah Temboro. Al-Manar, 9(1), 125-164.

Baharun, H., \& Mahmudah, M. (2018). Konstruksi Pendidikan Karakter Di Madrasah Berbasis Pesantren. Jurnal Mudarrisuna: Media Kajian Pendidikan Agama Islam, 8(1), 149-173.

Dahlan, Z. (2016). Internalisasi Pendidikan Karakter Perspektif Pesantren. Falasifa: Jurnal Studi Keislaman, 7(1), 155-172.

Gazali, E. (2018). Pesantren di antara generasi alfa dan tantangan dunia pendidikan era revolusi industri 4.0. OASIS: Jurnal Ilmiah Kajian Islam, 2(2), 94-109.

Hasan, N. (2016). Model Pembelajaran Berbasis Pondok Pesantren Dalam Membentuk Karakter Siswa Di Pondok Pesantren Raoudhotut Tholibin Rembang Jawa Tengah. Wahana Akademika: Jurnal Studi Islam Dan Sosial, 3(2), 92-110

Jannah, M. (2019). Metode dan strategi pembentukan karakter religius yang diterapkan di sdtq-t an najah pondok pesantren cindai alus martapura. AlMadrasah: Jumal Pendidikan Madrasah Ibtidaiyah, 4(1), 77-102.

Maarif, M. A. (2018). Analisis Strategi Pendidikan Karakter Melalui Hukuman Preventif. Ta'allum: Jurnal Pendidikan Islam, 6(1),

Mu'is, A. (2021). Manajemen Pengembangan SDM di Pondok Pesantren As-syafaah Kebonsari Jember. Fenomena, 20(1), 33-44.

Nopianti, R. (2018). Pendidikan Ahlak sebagai Dasar Pembentukan Karakter di Pondok Pesantren Sukamanah Tasikmalaya. Patanjala, 10(2), 291819.

Qosidah, S., Nurhadi, N., \& Zuhri, I. M. (2019). Desain pendidikan karakter berbasis pondok pesantren; studi pondok pesantren alkaromah bali. Fenomena, 17(1).

Ramdhani, K., \& Waluyo, K. E. (2019). Peranan Pendidikan Agama Islam Dalam Upaya Internalisasi Karakter Di Pondok Pesantren Nihayatul Amal Rawamerta Karawang. Jurnal Hadratul Madaniyah, 6(2), 1-15.
Risnawati, R., \& Vitasari, R. A. (2020). Implikatur percakapan santri putri sebagai upaya penguatan pendidikan karakter pondok pesantren generasi 4.0. KoPeN: Konferensi Pendidikan Nasional, 2(1), 243-247.

Rodliyah, S. (2016). Manajemen pondok pesantren berbasis pendidikan karakter (Studi Kasus di Pondok Pesantren "Annuriyyah" Kaliwining Kecamatan Rambipuji Kabupaten Jember). Cendekia: Jurnal Kependidikan Dan Kemasyarakatan, 12(2), 299-314.

Shofiyyah, N. A., Ali, H., \& Sastraatmadja, N. (2019). Model pondok pesantren di era milenial. Belajea: Jurnal Pendidikan Islam, 4(1), 118.

Sumardi, K. (2012). Potret Pendidikan Karakter di Pondok Pesantren Salafiah. Jurnal Pendidikan Karakter, (3).

Supratno, H., Hubandiyah, H., \& Raharjo, R. P. (2018). Pendidikan karakter di pondok pesantren sebagai media pencegahan radikalisme santri. Prosiding Semnas PPM 2018, 1(1), 19091919.

Wiranata, R. R. S. (2019). Tantangan, Prospek dan Peran Pesantren dalam Pendidikan Karakter di Era Revolusi Industri 4.0. AlManar, 8(1), 61-92.

Zuhriy, M. S. (2011). Budaya pesantren dan pendidikan karakter pada pondok pesantren salaf. Walisongo: Jurnal Penelitian Sosial Keagamaan, 19(2), 287-310.

Zulfiati, H. M. (2019, June). Pendidikan Karakter Perspektif Ki Hadjar Dewantara Dalam Membentuk Generasi Unggul Era Revolusi Industri 4.0. In Prosiding Seminar Nasional PGSD UST (Vol. 1). 